\title{
PENERAPAN FUZZY INFERENCE SYSTEM SUGENO UNTUK MENENTUKAN JUMLAH PEMBELIAN OBAT (STUDI KASUS: GARUDA SENTRA MEDIKA)
}

\author{
Sartika Lina Mulani Sitio \\ Teknik Informatika Universitas Pamulang \\ e-mail : dosen00847@unpam.ac.id
}

\begin{abstract}
ABSTRAK
Tujuan dari penelitian ini adalah untuk mengetahui jumlah pembelian obat di garuda sentra medika dengan sistem inferensi fuzzy metode sugeno berdasarkan data persediaan dan data penjualan. Penelitian ini menggunakan tiga variabel yaitu persediaan, penjualan dan pembelian dengan memiliki dua input yaitu persediaan dan penjualan dan satu output yaitu pembelian. Hasil dari penerapan fuzzy metode sugeno ini dapat membantu pihak perusahaan untuk menentukan jumlah pembelian obat dengan tingkat keberhasilan $88,88 \%$.
\end{abstract}

Kata kunci: Fuzzy Inference System, pembelian produk, persediaan, penjualan.

\section{PENDAHULUAN}

Ketersediaan bahan baku yang tepat sangat terkait dengan jumlah produk yang akan diproduksi. Oleh karena itu prediksi produksi harus disesuaikan agar pemesanan stok bahan baku dapat diperhitungkan dengan tepat. Masalah persediaan merupakan permasalahan yang selalu dihadapi para pengambil keputusan dalam bidang persediaan. Persediaan dibutuhkan karena pada dasarnya pola permintaan tidak beraturan. Persediaan dilakukan untuk menjamin adanya kepastian bahwa pada saat dibutuhkan produk-produk tersebut tersedia (Sunyoto, 2015). Masalah dalam persediaan adalah kesulitan dalam menentukan besarnya jumlah persediaan yang harus disediakan dalam memenuhi jumlah permintaan terhadap konsumen.

Kekurangan persediaan dapat berakibat terhentinya proses produksi, dan ini menunjukkan persediaan termasuk masalah yang cukup krusial dalam operasional perusahaan. Besarnya nilai buffer stock dipengaruhi oleh besarnya permintaan dan waktu pesan supply. Terlalu besarnya persediaan atau banyaknya persediaan (over stock) dapat berakibat terlalu tingginya beban biaya guna menyimpan dan memelihara bahan selama penyimpanan di gudang padahal barang tersebut masih mempunyai opportunity cost (dana yang bisa ditanamkan / diinvestasikan pada hal yang lebih menguntungkan).
Garuda sentra medika (GSM) adalah sebuah unit bisnis strategis dari PT. Garuda Indonesia (persero) yang memiliki fungsi utama melaksanakan pengelolaan fasilitas kesehatan dan pelayanan kesehatan untuk karyawan Garuda Group beserta keluarganya, serta pihak-pihak lain yang membutuhkan. Garuda sentra medika didirikan pada tahun 1949 yang memiliki beberapa cabang di cikokol, bekasi dan bintaro. Garuda sentra medika telah melakukan pengelolaan kesehatan dengan jumlah peserta mencapai hampir 35.000. (Berdasarkan data di garuda sentra medika)

Garuda Sentra Medika merupakan salah satu perusahaan retail yang sering mengalami masalah dalam persediaan obat. Salah satu masalah yang sering terjadi pada perusahaan ini adalah jumlah persediaan terlalu banyak dan tertumpuk lama sehingga sering sekali banyak obat yang sudah kadaluarsa atau expired. Keadaan ini menyebabkan perusahaan mengeluarkan biaya yang lebih besar karena banyaknya barang yang sudah kadaluarsa. Sebaliknya, apabila persediaan terlalu besar dan tidak sebanding dengan jumlah permintaan/penjualan, perusahaan akan mengalami kerugian akibat pertambahan biaya bunga uang modal yang tertanam dalam persediaan, pajak, asuransi, biaya penyusutan, penurunan harga, dan kerusakan akibat telah mencapai masa expire (Sunyoto, 2015). 
Untuk mengatasi hal ini, maka diperlukan analisa dan pengolahan data historis transaksi penjualan dengan tujuan untuk menentukan tingkat persediaan yang harus tersedia serta kapan pembelian kembali dilakukan untuk menambah persediaan. Hal ini diperlukan untuk menjamin tersedianya persediaan yang tepat dalam kuantitas dan waktu yang tepat.

Pada penelitian ini menggunakan penerapan metode Fuzzy Inference System, dapat digunakan untuk menentukan jumlah dan kapan waktu pembelian produk untuk persediaan. Logika fuzzy dianggap mampu untuk memetakan suatu input kedalam suatu output tanpa mengabaikan faktor-faktor yang ada. Logika fuzzy diyakini sangat fleksibel dan memiliki toleransi terhadap data-data yang ada. Berdasarkan logika fuzzy, akan dihasilkan suatu model dari suatu sistem yang mampu memperkirakan pembelian obat untuk persediaan. Faktor-faktor yang mempengaruhi dalam menentukan pembelian obat untuk persediaan dengan logika fuzzy antara lain pembelian, persediaan dan penjualan. Optimasi jumlah pengadaan obat yang optimal merupakan bagian dari penentuan jumlah pengadaan obat, dan salah satu cara pengambilan keputusan dalam optimasi jumlah pengadaan yang optimal tersebut adalah dengan menggunakan Logika Fuzzy metode sugeno karena sistem fuzzy Sugeno memperbaiki kelemahan yang dimiliki oleh sistem fuzzy murni untuk menambah suatu perhitungan matematika sederhana sebagai bagian THEN. Pada perubahan ini, system fuzzy memiliki suatu nilai rata-rata tertimbang (Weighted Average Values) di dalam bagian aturan fuzzy IFTHEN

\section{LANDASAN TEORI}

Obat

Obat merupakan sediaan atau paduan bahan-bahan yang siap untuk digunakan untuk mempengaruhi atau menyelidiki sistem fisiologi atau keadaan patologi dalam rangka penetapan diagnosis, pencegahan, penyembuhan, pemulihan, peningkatan, kesehatan dan kontrasepsi (Kebijakan Obat Nasional, Departemen Kesehatan RI,2005).

Obat dalam arti luas ialah zat kimia yang dapat mempengaruhi proses hidup, maka farmakologi merupakan ilmu yang sangat luas cakupannya. Namun untuk seorang dokter, ilmu ini dibatasi tujuannya yaitu agar dapat menggunakan obat untuk maksud pencegahan, diagnosis, dan pengobatan penyakit. Selain itu, agar menegrti bahwa penggunaan obat dapat mengakibatkan berbagai gejala penyakit. (Bagian Farmakologi Fakultas Kedokteran, Universitas Indonesia).

Menentukan Persediaan Produk

Ketersediaan produk dapat menentukan presentase permintaan pasar terhadap beberapa SKU yang memuaskan. Semakin tinggi persediaan barang dagangan, semakin besar stok cadangan. Memilih jumlah cadangan yang tepat adalah kunci sukses dalam proses perencanaan keberagaman, karena jika cadangan barang terlalu rendah maka peritel akan kehilangan penjualan dan pelanggan. Jika stok barang terlalu tinggi, ditakutkan sumber daya keuangan dan investasi yang seharusnya dapat digunakan untuk membeli barang lain yang lebih menguntungkan akan terbuang percuma (Sunyoto, 2015).

\section{Fuzzy Logic}

Logika fuzzy adalah suatu cara yang tepat untuk memetakan suatu ruang input kedalam suatu ruang output. Titik awal dari konsep modern mengenai ketidakpastian adalah paper yang dibuat oleh Lofti A Zadeh (1965), dimana Zadeh memperkenalkan teori yang memiliki obyek-obyek dari himpunan fuzzy yang memiliki batasan yang tidak presisi dan keanggotaan dalam himpunan fuzzy, dan bukan dalam bentuk logika benar (true) atau salah (false), tapi dinyatakan dalam derajat (degree). Konsep seperti ini disebut dengan Fuzziness dan teorinya dinamakan Fuzzy Set Theory. Fuzziness dapat didefinisikan sebagai logika kabur berkenaan dengan semantik dari suatu kejadian, fenomena atau pernyataan itu sendiri.

\section{Metode Sugeno}

Model Fuzzy Sugeno ( model fuzzy TSK ) diajukan oleh Takagi, Sugeno, dan Kang ( Takagi dan Sugeno, 1985) dalam upaya untuk membangun pendekatan sistematis untuk membangkitkan aturan aturan fuzzy dari himpunan data input - 
output yang diberikan. Suatu aturan fuzzy khas dalam model fuzzy Sugeno dibentuk:

if $x$ is $A$ and $y$ is $B$ then $z=f(x, y)$, dimana $A$ dan $B$ himpunan fuzzy dalam anteseden dan $z=f(x, y)$ fungsi tegas dalam konsekuen. Jika $f(x, y)$ polimonial orde satu, FIS yang dihasilkan disebut model fuzzy Sugeno orde satu. Jika $f$ konstan, dihasilkan model fuzzy Sugeno orde nol.

Sistem inferensi fuzzy menggunakan metode Sugeno memiliki karakteristik, yaitu konsekuen tidak merupakan himpunan fuzzy, namun merupakan suatu persamaan linear dengan variabel - variabel sesuai dengan variabel - variabel inputnya.

\section{METODE PENELITIAN Pengunpulan Data}

Tabel 3.1 Sampel Data

\begin{tabular}{|c|c|c|c|}
\hline \multirow{2}{*}{$\begin{array}{c}\text { Tahun } \\
\text { 2015/2016 }\end{array}$} & \multicolumn{3}{|c|}{ Nexium 40 mg Tab } \\
\cline { 2 - 4 } & Persediaan & Penjualan & Pembelian \\
\hline Januari & 246 & 284 & 75 \\
\hline Pebruari & 37 & 243 & 250 \\
\hline Maret & 44 & 150 & 200 \\
\hline April & 94 & 48 & 120 \\
\hline Mei & 166 & 92 & 0 \\
\hline Juni & 74 & 141 & 90 \\
\hline Juli & 49 & 190 & 175 \\
\hline Agustus & 34 & 75 & 100 \\
\hline September & 59 & 58 & 120 \\
\hline Oktober & 121 & 146 & 80 \\
\hline November & 55 & 131 & 100 \\
\hline Desember & 25 & 140 & 140 \\
\hline Januari & 94 & 48 & \\
\hline
\end{tabular}

\section{Proses Fuzzy Inference System}

Tabel 3. 4 Aturan Fuzzy dalam Pembelian Produk untuk Persediaan

\begin{tabular}{|c|l|l|}
\hline \multirow{2}{*}{ Aturan } & \multicolumn{2}{|c|}{ INPUT } \\
\cline { 2 - 3 } & Persediaan & Penjualan \\
\hline R1 & Sedikit & Sedikit \\
\hline R2 & Sedikit & Sedang \\
\hline R3 & Sedikit & Banyak \\
\hline
\end{tabular}

\begin{tabular}{|l|l|l|} 
R4 & Sedang & Sedikit \\
\hline R5 & Sedang & Sedang \\
\hline R6 & Sedang & Banyak \\
\hline R7 & Banyak & Sedikit \\
\hline R8 & Banyak & Sedang \\
\hline R9 & Banyak & Banyak \\
\hline
\end{tabular}

Setelah penentuan fungsi keanggotaan variabel, maka dilakukan pembentukan aturan logika fuzzy. Berdasarkan data - data yang ada, dapat dibentuk aturan - aturan sebagai berikut:

1. if (Persediaan is Sedikit) and (Penjualan is Sedikit) then (Pembelian Sedikit)

2. if (Persediaan is Sedikit) and (Penjualan is Sedang) then (Pembelian Sedang)

3. if (Persediaan is Sedang) and (Penjualan is Banyak) then (Pembelian Banyak)

4. if (Persediaan is Sedang) and (Penjualan is Sedikit) then (Pembelian Sedikit)

5. if (Persediaan is Sedang) and (Penjualan is Sedang) then (Pembelian Sedang)

6. if (Persediaan is Sedang) and (Penjualan is Banyak) then (Pembelian Banyak)

7. if (Persediaan is Banyak) and (Penjualan is Sedikit) then (Pembelian Sedikit)

8. if (Persediaan is Banyak) and (Penjualan is Sedang) then (Pembelian Sedang

9. if (Persediaan is Banyak and (Penjualan is Banyak) then (Pembelian Banyak)

\section{Proses Defuzzification}

Proses defuzzification untuk data pertama yaitu jenis obat Nexium $40 \mathrm{Mg}$. Untuk menentukan jumlah pembelian pada bulan januari 2016, maka dibutuhkan data persediaan awal januari 2016 dan data penjualan pada januari 2016. Dari data yang saya peroleh, jumlah persediaan nexium 40 Mg pada awal januari adalah 94 dan jumlah penjualan nexium $40 \mathrm{Mg}$ pada akhir januari adalah 48 . 
Untuk himpunan fuzzy persediaan sedikit adalah :

$$
\mu(x 1)=\frac{125-94}{125}=0.25
$$

untuk himpunan fuzzy penjualan sedikit adalah

$$
\mu \operatorname{Sedikit}(y)=\frac{94-62,5}{125}=0.7
$$

Dari 9 rule yang telah ada dan dengan memasukkan nilai keanggotaan $\mu(x 1)$ dan $\mu(x 2)$ dan $\mu(y 1)$, maka fungsi implikasi akan menghasilkan $\alpha$ - predikat dari masing masing aturan yaitu:

$\mathrm{R} 1$ = If persediaan sedikit is penjualan sedikit then pembelian = persediaan penjualan.

$$
\begin{aligned}
& \quad \alpha-\text { predikat } 1=\min (\mu(x 1) \cap \mu(y 1)) \\
& =\min [0,25 ; 1] \\
& =0,25 \\
& \text { Nilai: } z_{1}: z_{1}=94-48 \\
& =46
\end{aligned}
$$

$\mathrm{R} 2=$ If persediaan sedikit is penjualan sedang then pembelian $=$ persediaan $-\left(1,18^{*}\right.$ penjualan)

$$
\begin{aligned}
& \quad \alpha \text {-predikat } 2=\min (\mu(x 1) \cap \mu(y 2)) \\
& =\min [0,25 ; 0] \\
& =0 \\
& \text { Nilai: } z_{2}: z_{2}=94-(1,18 * 48) \\
& =37,36
\end{aligned}
$$

$\mathrm{R} 3$ = If persediaan sedikit is penjualan banyak then pembelian $=$ persediaan penjualan

$$
\begin{aligned}
& \alpha-\text { predikat } 3=\min (\mu(x 1) \cap \mu(y 3)) \\
& =\min [0,25 ; 0] \\
& =0 \\
& \text { Nilai: } z_{3}: z_{3}=94-48 \\
& =46
\end{aligned}
$$

$\mathrm{R} 4=$ If persediaan sedang is penjualan sedikit then pembelian $=\left(1,25^{*}\right.$ persediaan $)-$ penjualan

$$
\begin{aligned}
& \alpha-\text { predikat } 4=\min (\mu(x 2) \cap \mu(y 1)) \\
& =\min [0,7 ; 1] \\
& =0,7 \\
& \text { Nilai: } z_{4}: z_{4}=(1,25 * 94)-48 \\
& =69,5
\end{aligned}
$$

$\mathrm{R} 5$ = If persediaan sedang is penjualan sedang then pembelian $=$ persediaan

$$
=\min [0,7 ; 0]
$$

$=0$

Nilai: $z_{5}: z_{5}=94$

R6 = If persediaan sedang is penjualan banyak then pembelian $=$ penjualan $\alpha$ - predikat6 $=\min (\mu(x 2) \cap \mu(y 3))$

$=\min [0,7 ; 0]$

$=0$

Nilai: $z_{6}: z_{6}=48$

$\mathrm{R} 7$ = If persediaan banyak is penjualan sedikit then pembelian $=(1,125 *$ persediaan $)$ - penjualan

$$
\begin{aligned}
& \quad \begin{array}{l}
\alpha-\text { predikat } 7=\min (\mu(x 3) \cap \mu(y 1)) \\
=
\end{array}=\min [0 ; 1] \\
& =0
\end{aligned}
$$

Nilai: $z_{7}: z_{7}=(1,125 * 94)-48$ $=57,75$

$\mathrm{R} 8=$ If persediaan banyak is penjualan sedang then pembelian $=$ penjualan

$$
=\min [0 ; 0]
$$$$
\alpha \text {-predikat } 8=\min (\mu(x 3) \cap \mu(y 2))
$$

$=0$

Nilai: $z_{8}: z_{8}=48$

$\mathrm{R} 9=$ If persediaan banyak is penjualan banyak then pembelian $=$ persediaan

$$
\begin{aligned}
& \alpha \text { - predikat } 9=\min (\mu(x 3) \cap \mu(y 3)) \\
& =\min [0 ; 0] \\
& =0 \\
& \text { Nilai: } z_{5}: z_{5}=94
\end{aligned}
$$

Maka berdasarkan aturan diatas, metode yang digunakan adalah metode fuzzy sugeno dengan menggunakan metode defuzzy weighted average. Dimana, aturan $\alpha-$ predikat yang digunakan adalah yang bukan nol yang terdapat pada R1 dan R4, sehingga:

$$
\begin{aligned}
Z & =\frac{(\alpha-\text { predikat } * \mathrm{Z} 1)+(\alpha-\text { predikat } 4 * \mathrm{Z} 4)}{\alpha-\text { predikat } 1 \quad \alpha-\text { predikat } 4} \\
& =\frac{(0,25 * 46)+(0,7 * 69,5)}{(0,25+0,7)} \\
& =\frac{11,6+48,65}{0,95} \\
& =63,4 \\
& =63
\end{aligned}
$$

Kesimpulannya, untuk jumlah persediaan 94 dan penjualan 48 pada bulan desember 2015, maka jumlah pembelian obat nya sebesar 63 .

\section{HASIL DAN PEMBAHASAN}




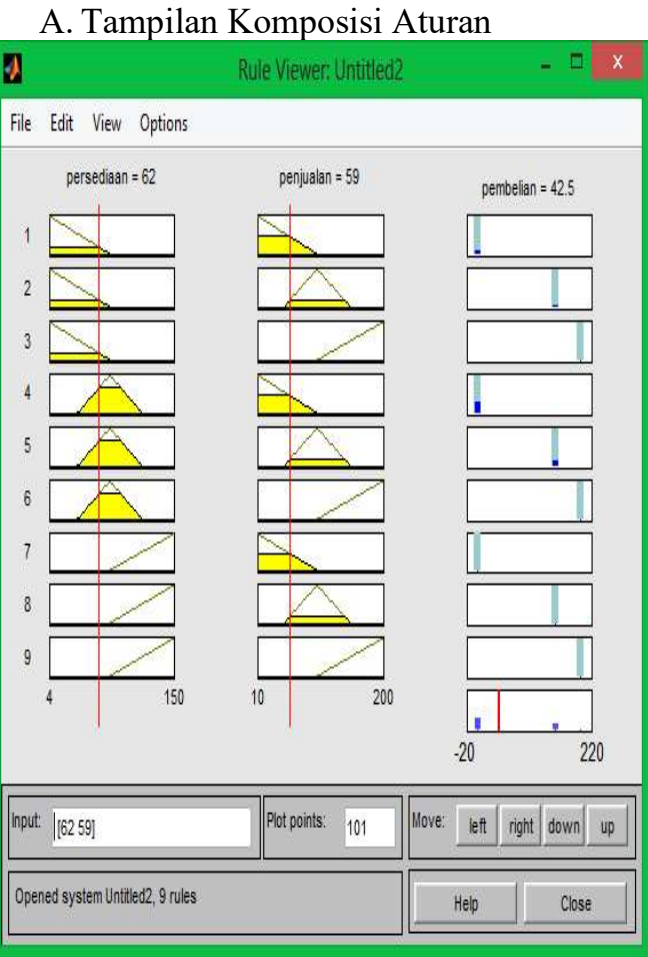

Gambar 4. 1 Tampilan Komposisi Aturan

B. Tampilan Diagram Metode Sugeno

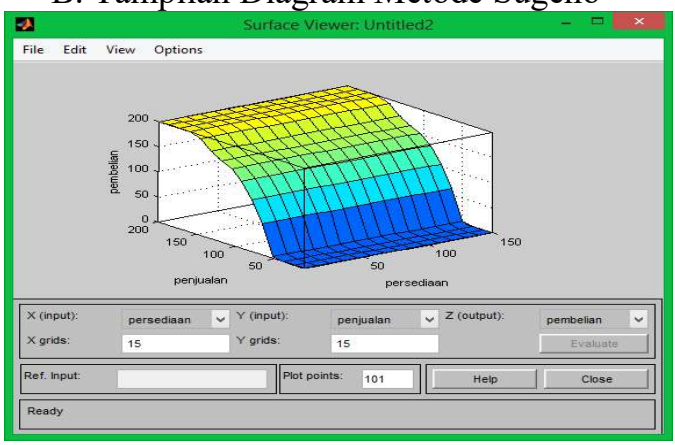

Gambar 4. 2 Tampilan Diagram Metode Sugeno

C. Pengujian Data

Dari penelitian yang sudah dilakukan maka didapat hasil perbandingan penilaian Logika Fuzzy Sugeno dengan menggunakan persentase rata-rata atau Mean Absolute Percentage Error (MAPE) dengan rumus:

$$
\text { MAPE }=\frac{\text { Actual }- \text { Forecast }}{\text { Actual }} \times 100 \%
$$

\section{Keterangan:}

MAPE

$=$ Mean Absolute Percentage Error

\author{
$Y_{t}$ \\ $=$ Nilai data time series pada periode $t$ \\ Forecast \\ = Nilai ramalan data dari actual
}

Tabel 4. 1 Hasil Pengujian Data

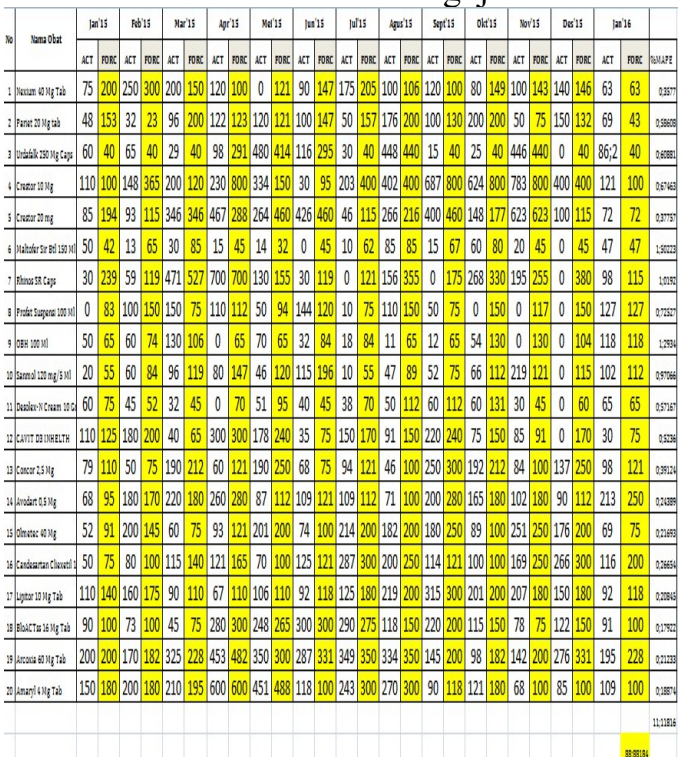

\section{PEMBAHASAN}

Dari hasil pengujian yang telah dilakukan, diperoleh jumlah MAPE yang digunakan adalah sebesar 11,12\% sehingga dapat dikatakan bahwa tingkat keberhasilan yang diperoleh sebesar $88,88 \%$. Sehingga fuzzy sugeno dapat digunakan untuk menentukan jumlah pembelian obat berdasarkan data persediaan dan penjualan.

Hasil persentasi pengujian data yang dilakukan dapat dilihat pada bagan berikut:

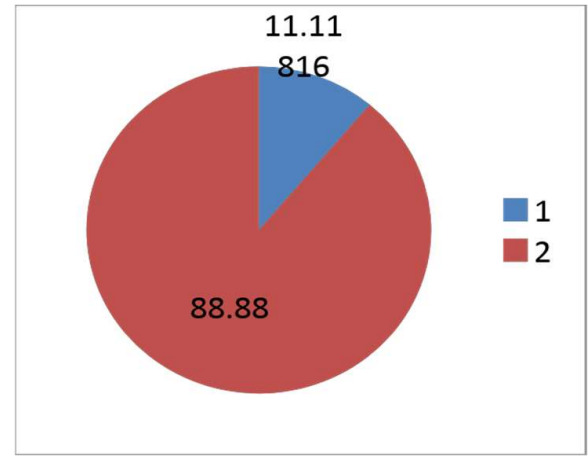

Bagan 4. 1 Tingkat Kesalahan dan Kebenaran pada Pengujian Data 


\section{KESIMPULAN}

Berdasarkan pembahasan mengenai Metode Fuzzy Sugeno dalam menentukan jumlah pembelian obat berdasarkan data persediaan dan data penjualan maka dapat disimpulkan:

1. Berdasarkan pengujian dan perhitungan yang sudah dilakukan maka logika fuzzy dengan metode sugeno dapat membantu pihak perusahaan dalam menentukan jumlah pembelian obat berdasarkan data persediaan dan data penjualan.

2. Dari hasil uji coba yang dilakukan dengan metode fuzzy sugeno, maka tingkat keberhasilan dalam menentukan pembelian obat mencapai $88,02 \%$ dari 20 jenis data obat yang dipilih secara acak.

\section{SARAN}

Saran-saran yang dapat digunakan untuk penelitian berikutnya untuk mencapai hasil yang lebih baik diantaranya:

1. Untuk mempermudah pengoperasian pengolahan data perlu dibuat program aplikasi yang menerapkan metode fuzzy inference system.

2. Perlu dilakukan penelitian selanjutnya dengan menggunakan metode Fuzzy CMean (FCM), Adaptive Neuro-Fuzzy Inference System (ANFIS), dan Jaringan syaraf tiruan (Artificial Neural Network) yang diharapkan dapat mendapatkan hasil yang lebih akurat.

3. Jumlah data yang digunakan untuk pengujian data harus lebih banyak lagi.

\section{DAFTAR PUSTAKA}

Sunyoto, D. (2015). Manajemen Bisnis Ritel. Jakarta: CAPS (Center for Academic Publishing Service)

Fazri Zufa (2014). Perbandingan SistemInferensi Fuzzy Metode Mamdani dan Metode Sugeno Dalam Memprediksi Laju Inflasi. Jurnal Matematika, F.MIPA.

Miranda, S (2010). Penentuan Jumlah Produksi Kue Bolu Pada Nella Cake Padang Dengan Sistem Inferensi Fuzzy Metode Sugeno.

Adiputra, K, dkk.(2015). Analisis Fuzzy Inference System Sugeno dan Tsukamoto Dalam Menentukan Jumlah Produksi Dengan Aplikasi Web.

Suwandi, dkk. (2011). Aplikasi Sistem Inferensi
Fuzzy Metode Sugeno Dalam

Memperkirakan Produksi Air Mineral Dalam Kemasan

Brahara, B. (2009). Implementasi Metode Fuzzy Mamdani Untuk Menentukan Jumlah Produksi Berdasarkan Jumlah Permintaan dan Data Persediaan.

Sri Kusuma Dewi, H. P. (2013). Aplikasi Logika Fuzzy Untuk Pendukung Keputusan. Yogyakarta: Graha Ilmu. 